\title{
AGE-SET SYSTEM AMONG THE BABUKUSU OF WESTERN KENYA
}

\author{
Godfrey Banda Mayende \\ PhD Student at Laikipia University-Kenya, Department of Public Affairs and Environmental Studies
}

Article DOI: https://doi.org/10.36713/epra9288

DOI No: 10.36713/epra9288

\begin{abstract}
This paper was extracted from a Master of Arts Degree (History) thesis which was submitted to Graduate School of Kenyatta University in April 2017. The study interrogated the Impact of the Inter-Christian Fellowship Evangelical Mission on circumcision Rituals among the Babukusu of Kimilili Constituency. However, this paper traces the origin and the development of circumcision concepts among Babukusu, emphasizing on age-sets that are closely attached to this initiation ritual. It gives a historical perspective of this rite that has been examined by social Anthropologists. To achieve this, the adoption of interview schedules was very paramount and as such, knowledgeable informants were subjected to Oral Interviews whose data was corroborated with other secondary sources to ascertain relevant historical facts. That aside, significant information was collected from the Kenya National Archives and this was a crucial source towards the development of this paper.
\end{abstract}

KEY WORDS; bakolongolo, bakikwameti, bakananachi, bakinyikeu, babanyange, bamaina, bachuma and basawa.

\section{INTRODUCTION}

Babukusu constitute the seventeen sub-nations that comprise the Luyia cluster of the Bantu of Eastern Africa. Other communities within Luhya of western Kenya include Baragoli, Batiriki, Banyore, Bakabras, Batachoni, Babesukha, Banyala, Bamarachi, Basamia, Babesukha, Babedakho, Bakisa, Barechea, Batsotso, Bawanga, Bamarama and Batura (Wanyama, 2017: 26). Babukusu largely occupy Bungoma and Trans-Nzoia Counties in Western Kenya although a few of them inhabits several pockets of Kakamega and Busia Counties.

Among other significant cultures associates with Babukusu, circumcision is one of them that has been held with high esteem implicit of others which are equally important. This postulation is in consonant with Muraya (2009: 41) who argues that circumcision rite is deeply embedded in the social psychology, cultural, symbolism, values and norms among African communities. It's important to posit that there is no proven historical evidence of female circumcision among the Babukusu unlike other communities in Kenya. Possibly, that is why Lihraw (2010: 147) excludes the Babukusu from the Kenyan communities which practiced female circumcision.
Male circumcision among the Babukusu contains a myriad of rituals constituting coded significant values and norms both to the initiates and the community. Wanyama (2017: 67) supports this by arguing that Bukusu circumcision is characterized by taboos and beliefs that are depicted in the actions of participants through various rituals. Similarly, Silverman (1995: 45) states that male circumcision in Africa is associated with symbolic themes like the enhancement of masculine virility, arboreal fertility, complementary opposition between men and women, preparation for marriage and adult sexuality and the hardening of boys for war.

Therefore, age-set system is a circumcision rite that has been practiced for ages in the historicity of the Babukusu. It is post-circumcision ritual which plays a vital role in the Bukusu community and it only ceases to exist upon the demise of members of a particular age-set. And yet those who are alive have the obligation of remembering these past age-sets and they also have the mandate of teaching their next generations such past history through oral tradition. 


\section{OBJECTIVE OF THE STUDY}

The main objective in this study was to give a historical analysis of the age-set system as portrayed in the Bukusu circumcision culture.

\section{RESEARCH METHODOLOGY}

This research relied on field interviews (abbreviated as O.I) through which informants were selected using purposive and snowball sampling techniques who were interrogated to generate the findings in this paper (see a list of informant attached). The Kenya National Archives (abbreviated as KNA) was consulted in advancing circumcision situation among the Babukusu during the colonial period.

\section{HISTORICAL BACKGROUND OF BUKUSU CIRCUMCISION}

In attempting to reconstruct the origin of circumcision of any community, what should be considered is the cradle land of that community. This is according to Kakai (1992: 33) who also posits that the origin of specific initiation concepts tie such concepts with the origin of that community. Likewise, the origin of Bukusu circumcision should be traced back from Misri, being the original homeland of Babukusu. According to oral traditions of the Misri theory, the first circumciser was a woman who used stones to conduct her trade (Naulikha, O.I, 2014). However, it is not clear how the woman went about with the process but what is known is that it was long time ago and the tools which were used for the ritual were crude ones. If well interrogated in a historical perspective, the period in contention here is the Stone Age period when tools were crude and were mostly made from stones.

In support of circumcision origin from Misri (Swahili word for Egypt) and possibly Abyssinia, Herodotus argues that circumcision in Egypt and Ethiopia was practiced from the very first time (cited in Mwanzi, 1977: 104-105). This argument is likely to support the Bukusu's claim of Misri as the antiquity of their circumcision ritual. While at Esirende for instance, the Babukusu disliked their Teso neighbours because they avoided circumcision (Makila 1978: 136). This is a clear indication that during their migration Southwards from Misri, they never abandoned the ritual completely despite many challenges they faced.

From Esirende, the Babukusu settled at a place called Esengeli but there is scanty evidence of circumcision at this place. The only primary evidence is finding out the meaning of the word Esengeli. Esengeli comes from a Bukusu word "lisenegeli" which means "the land of Iron slug" (Wandiba, 1983: 3). Esengeli is probably the historical Meroe which was located in the present day Sudan. That being the case, several tools such as circumcision knives (ching'embe), jingle bells (chinyimba) and bangles (birere) were made at Esengeli (Kakai, 1992:44). Spears and arrowheads that were used during the post initiation ritual of the passing out (khukhwiyalula) were also manufactured at this place. The existence of kamarumbi (blacksmith industries), where tools such as chinyimba and birere were manufactured among the Babukusu is a clear indication that circumcision rituals and other economic aspects like iron smelting were handed down from one generation to another.

From Esengeli, the Babukusu reached Silikwa and Makila (1978: 142) maintains that they had just circumcised the basawa before signs of external danger appeared on the horizons. Between Silikwa and Mwiala, Bukusu circumcision was stagnated by the nomadic conditions and the periodic spells of war. The ritual was still in the mind of the Babukusu but they ignored it partly because they had no time to organize circumcision ceremonies and partly because many uncircumcised men were afraid of facing the knife (Makila, 1978: 146). Again, kananachi age-set is also mentioned just before they settled at Mwiala. Oral traditions reveal that there was a Bukusu leader at Esilangile who had three wives. The third wife had three sons who were circumcised and were grouped in bakananachi age-set. Maina wa Nalukale, a pre-colonial Bukusu prophet was circumcised on the slopes of Sikulu sya Bukusu (Bukusu hill) in Eastern Uganda and he was clustered in the bakananachi age-set. The Babukusu then entered Mwiala where they experienced long periods of war and movement around Mt. Masaba (Mt. Elgon), thus neglecting circumcision practice.

The present day Bukusu circumcision ritual should be traced back to Mango, son of Bwayi and omukhurarwa by clan (Makila 1978:170) who lived at Mwiala. Mango had two sons whom he loved and according to oral traditions, there lived a notorious serpent called Khuruwe ya bebe at Mwiala which used to devour beasts and human beings that came along its way. At that moment, the Babukusu did not practice circumcision as seriously and systematically as their Barwa (Kalenjin stock) neighbours (KNA, DC/EN/3/2/4: 1929-1935). Moreover, circumcision was not compulsory for Bukusu men apart from those who were to take up leadership positions. The snake was feared even by the Barwa Bakinisu, yet they claimed to be men because of their circumcision.

One day, Mango's sons became victims of the serpent while they were grazing cattle. He was so enraged that he swore to kill the murderous monster single-handedly (Cheloti, O.I, 2014). People were amazed by Mango's solemn declaration. The Barwa people laughed at him saying;

"Mango, if you can kill that serpent, we will circumcise you and give you our daughter for a bride..." (Makila 1978:171)

Determined to kill the snake, Mango sharpened his sword (embalu), took his shield and went straight into the cave where the snake stayed. He was aware of how the serpent entered the cave and how it coiled itself resting the head at the entrance of the cave. Mango cut a piece of log and placed it at the exact spot where the snake used to rest its head. He stripped naked and then entered the cave hiding in a dark corner of the cave (Lo Liyong 1972:69). Meanwhile, crowds of people gathered around, observing from a distance of three kilometers or even more and they were all alert lest 
the serpent came upon them unaware. After a long and frightened wait, the serpent appeared. It took notice of the $\log$ but then turned without looking in the nooks of the cave. Those who waited from far thought that Mango was already dead (KNA, DC/EN/3/2/4: 1929-1935).

The snake curled its body into a heap and rested its head on the log. Mango tightened his grip on the embalu and lashed out a blow with the sword severing the serpent's head. In less than five minutes, the notorious and murderous snake was dead. Mango was a hero. He then moved out of the cave, gesturing and beckoning to the unbelieving crowd that the serpent was dead. However, this call had mixed reactions from the spectators. Some took to their heels thinking that Mango was running away from the snake while others thought he was crazy (Naulikha, O.I, 2014). A few reasonable and curious people wanted to know what happened. They rushed to congratulate him for being alive. When they reached the cave, they saw for themselves and they carried Mango and started singing jubilantly. This did not sound well with the Barwa. Makila (1967:174) records how they murmured:

"How can omusinde achieve such an incredible feat? We, the circumcised ones, have been scampering from this thing like frightened chicks. Mango must be circumcised now."

So, Mango agreed to be circumcised and when he was being escorted home for circumcision, his old mother burst into tears and cried:

"Wooeii, woeii! Mango my only son. Ahaaa, hooh, Mango, did I not tell you that this circumcision is painful? You have chosen it yourself. There you are."

The Babukusu turned these fateful words of Mango's mother into a song, thereby composing the famous sioyaye chant which is sang when escorting the candidate home from the mudding place to face the knife (Naulikha, O.I, 2014). After this heroic act, circumcision was made compulsory in Bukusuland and it became a public ordeal where a real man was to face the knife outside his father's house and in full glare of everybody. The age-set system which was almost being forgotten was revived (Were, 1967: 172-173).

\section{THE ORIGIN OF AGE-SET SYSTEM}

Age-set system is defined as social category, group and corporate social institution consisting of people of the same age, with common identity, maintaining close ties over a long period of time and together pass through a series of age-related statuses such as initiation (Makila, 1982: 123). It also refers to a group of people who were circumcised at a particular span of time for instance, ten years. Such people may not be age-mates and they may also lack common clan identity and they may not maintain close ties. What brings them together is the fact that they were initiated during a particular circumcision age-set period. In many African communities, age-set system and in particular the organization of men and women into age-sets acted as a bridge which enabled individuals to become members of a wider community that surpassed kinship or territorial relations (Dutto, 1975: 167).

Within a particular age-set among the Babukusu, there exist different age-groups depending on the number of circumcision seasons present. Each age-group is referred to as embaka (singular) or chimbaka (plural) (Makila, 1982: 124 and Kakai, 1993: 66). Between 1910 and 1920 for example, kikwameti age-set was named. However, each circumcision season was named depending on the prevailing events which took place during that season. The 1912 circumcision season was for instance named kikwameti namiranda while 1916 and 1918 were named kikwameti matofari and kikwameti muchele respectively (Kakai, 1993: 150). Therefore, kikwameti matofari forms a single agegroup (embaka) whose members salutes each other as bakoki.

There are eight age-sets among the Babukusu (Makila, 1982: 123). However, Wagner (1949: 375) claims that they were reduced to six after the sporadic practice of circumcision from 1911. Wagner's version should be reexamined because the initial eight age-sets of the Babukusu are still intact, an argument articulated eloquently by Kakai (1993: 65-66) and Wanyama \& Egesa (2015: 18). These agesets are; bakolongolo, bakikwameti, bakananachi, bakinyikeu, babanyange, bamaina, bachuma and basawa. It should be understood that these age-sets are not progressive, nor are they linear, but rather cyclic (Makila, 1982: 124 and Kakai, 1993: 66). They are arranged from the first to the last thus bakolongolo forms the first age-set and basawa the last age-set. However, this is subject to debates and further interrogations because Makhanu (I.O, 2015) argues that with cyclic nature of any concept, it is not easy to know the one which pioneered.

Each age-set appears once in a century. Arguably therefore each of them covers a period of ten years apart from the bachuma which has fourteen years. Before 1882, all age-sets had ten years but by 1884 (the year the sawa age-set was to start), two elderly men called Makutukutu Omukhurarwa and Lukhalabanda Enyama ya Ndosi who had been circumcised in the previous basawa age-set (1784 to 1794) were still alive (Nabisiolo, O.I, 2014). Therefore, the basawa age-set was postponed to 1888 because the two men died in 1884 thus prolonging the bachuma age-set from 1872 to 1886 . Due to this, it was agreed that any man who lived long enough to reach the next cycle of his circumcision ageset was to be killed (Naulikha, O.I, 2014). This was the culture since then and before any age-set was ushered in, inquiries were always made across the Bukusu community including the Bakisu of Uganda to ascertain that no person initiated in the previous age-set was still alive. The following is the order of the circumcision age-sets in Bukusu history for the last one hundred years. Bakolongolo (1900-1910), bakikwameti (1912-1922), bakananachi (1924-1934), bakinyikeu (1936-1946), babanyange (1948-1958), bamaina (1960-1970), bachuma (1972-1986) and basawa (19881998). The cycle then begun with bakolongolo in 2000 
which ended in 2010. Bakikwameti begun in 2012 and the age-set is expected to come to an end in 2022.

How did the Babukusu come up with these circumcision age-sets? Why did they decide to come up with them? The origin of these concepts are debatable and they depict specific historical events that happened among the Babukusu (Makila, 1982: 123). They also depict famous persons in the Bukusu community or their neighbours.

The origin of initiation and age-set system concepts among the Babukusu have several theories. Some scholars argue that the interaction between the Cushites and the Bantu led to the adoption of some cultural practices among these communities. The Cushites are said to have introduced ageset system and circumcision practices to the Bantu groups in Kenya (Ochieng', 2002: 24). It is also argued tha the Kalenjin community are responsible for the introduction of the age-set system among the Babukusu (Wagner, 1949: 376, Makila, 1978: 176-177 and Kakai, 1993: 65-66). Indeed, the Nandi age-set names have linguistic similarities with those found among the Babukusu.

Among the Nandi, the eight age-sets include mainek, sawe, chumo, korongoro, kipkoimet, kaplelach, kimnyige and nyongi (KNA, DC/EN/3/2/4: 1929-1935). However, the order in which these age-sets appear among the Nandi differs with how they are arranged among the Babukusu. The Nandi begins with mainek and ends with nyongi while the Babukusu begins with bakolongolo and end with basawa. This disparity makes people to doubt if really the Babukusu borrowed their age-set system from the Nandi (Banda, O.I, 2014). This is however subject to further arguments from other people who hold that Bukusu age-set system was influenced by the Kalenjin. In Wasike's (2013: 133-134) own words, "notably, the Bukusu use circumcision age-set names that appear to have strong links with the Kalenjin age-set names."

According to Makhanu (O.I, 2015), the cyclic nature of the age-set system makes it hard to sustain the argument that the Babukusu developed this culture independently. It is argued that with the cyclic nature of ageset system, it is not easy to know the one which pioneered thus ruling out the thought that the disparity in the occurrence of age-set system among the Babukusu and the Nandi creates doubt if really there was influence from either of the two communities.

\section{The Eight age-sets}

Bukusu oral traditions suggest that age-sets in this community emerged independently depending on the historical events that occurred at a particular period of time (Makila 1982: 123). Nabisiolo (O.I, 2014) argues that kolongolo is the oldest circumcision age-set which occurred when the Babukusu were in the haste of migration, probably from Misri (Egypt). The word kolongolo comes from a Bukusu word, khukolongola or khukolongokha, which means to pack everything that one owns and leave. Therefore, the first kolongolo age-set must have been initiated at the time when the Babukusu had just departed from Misri on their Southward course of migration.
This version concerning the origin of the kolongolo age-set however contradicts Kakai's (1993: 67) assertion which links this age-set with the famous serpent, khuruwe ya bebe at Mwalie. It is this snake that was killed by Mango at Mwiala after which Bukusu circumcision was resuscitated (Makila, 1978: 170-178). Mango is said to have launched his own breed of the kolongolo age-set in 1800 which Kakai (1993: 67) refers to as kolongolo khuruwe while Makila (1978: 176) calls it kolongolo khuruwe we bwayi. Ideally, this was one of the embaka of the kolongolo but not the genesis of the entire kolongolo age-set.

Furthermore, Kakai's argument that kolongolo was the very first age-set to have taken place between 1800 and 1810 should also be re-examined. Makila (1982: 178) posits that mass public circumcisions were absent among the Babukusu, just as ceremonial pomp was absent and age-sets were not strictly adhered to. Seemingly, Wandiba (1983: 7) also suggests that age-set system was present among the Batachoni before 1800. Wandiba gives a brief exposition of a Tachoni leader called Kiboriti who was circumcised during the basawa age-set between 1784 and 1794. This illustrates that age-set system was present in the Bukusu society before 1800. It is from Mango onwards that the regimentation of the Bukusu society into circumcision age-sets became more permanent (Makila, 1978: 176).

Kikwameti age-set was associated with a stubborn community which did not allow the Babukusu penetrate their land during migration. The community is believed to be the Kalenjin stock and its brave leader marshalled warriors to form a non-permeable defense which the Babukusu were unable to conquer (Nabisiolo, O.I, 2014). This leader was called Kipkoimet hence Bukusu boys who were circumcised during this period acquired the age-set name kikwameti. This is a linguistic distortion of the Kalenjin's word, kipkoimet (Nabiswa, O.I, 2014).

Faced with the challenge of passing through this community, Bukusu elders began to think of their next move. In lubukusu language, thinking is called khukanakana and people who think are referred to as Babandu Bakanakana. So, when elders kept on thinking on how to pass through this community, a new group of boys was circumcised and to keep this event in memory, these boys were categorized into the bakananachi age-set (Cheloti, O.I, 2014).

Eventually, Babukusu managed to pass across the stubborn community but they were again faced with the hurdle of settling in the greener pastures they acquired. It took a good period of time for them to settle. Settling in lubukusu language is called khukinya. According to Wamalwa (O.I, 2014), this settlement enabled the Babukusu to prosper in wealth which resulted from a lengthy period of political stability within their vicinity. Boys who were circumcised during this period were called bakinyikeu to commemorate how the Babukusu laboured to settle in their new land and how they eventually acquired wealth.

Babanyange age-set is closely linked to the period that followed shortly after the bakinyikeu age-set. The age- 
set was primarily characterized by optimum wealth and material acquisition, especially in livestock keeping (Nabisiolo, O.I, 2014). Nyange comes from the Bukusu word, enyange (singular) or chinyange (plural). Chinyange (cattle egret) refers to particular type of birds which always accompany cattle to the grazing fields (Beruldsen, 2003: 182). They are white in colour and they are always in large numbers in a particular grazing field. Wamalwa (O.I, 2014) argues that the birds appeared for the first time during the initiation period that followed the kinyikeu and during this time, the Babukusu had prospered in livestock keeping. Due to this, Bukusu elders named this age-set babanyange.

According to Wasike (O.I, 2014), the origin of bamaina age-set is associated with a Bukusu leader whose leadership was remarkable after the Babukusu settled in their new territory. He was known as Maina and he is said to have been the leader of the Sheba kingdom that was situated in the current state of Ethiopia. This claim is however subject to further interrogations to ascertain its truth. Contradicting the above version on the origin of bamaina, Wamalwa (O.I, 2014) links this age-set with a group of people who lavishly enjoyed and extravagantly spent the wealth accrued by bakinyikeu and babanyange. It is contended that the aftermath of bamaina was disastrous hence the next age-set was determined to revitalize the economic wellbeing of their community.

Bamaina was followed bachuma age-set. It is believed that a time came in the history of the Babukusu when there was the discovery and the use of iron. In Lubukusu language, iron is called sibia or sichuma (Makila, 1978: 139-140). Therefore, boys who were circumcised when iron was in use were given the age-set name bachuma. This circumcision age-set may have taken place in Meroe where iron ore was largely deposited.

The last circumcision age-set in Bukusu history is basawa. The name basawa comes from a Bukusu word khusaula which means cutting and killing people using machetes and other sharp objects (Nabisiolo, O.I, 2014). From Meroe Babukusu entered a very fertile land where they fought its inhabitants to occupy it resulting to bloodshed and death. That is how boys who were initiated during that period were referred to as basawa. It is argued that whenever this age-set is circumcised, the Babukusu must go to war with any community neighbouring them.

Cultural experts of Bukusu circumcision argue that events which occurred during the previous age-set will always appear in the same age-set after one hundred years. During the basawa age-set of 1888 to 1898 for instance, there was fighting between the Babukusu and the British during the famous Lumboka/Kibachenje-Chetambe War (1894-1895) (Wafula, 2000: 102-120). Coincidentally, basawa age-set of 1988-1998, was marked by the famous Bukusu-Sabaot ethnic clashes that were instigated by the clamour for multi-party democracy in Kenya in 1992.

That aside, the kolongolo age-set (1900-1910) was characterized by the forceful migration of Africans by the colonial government due to ordinances which alienated
African land from the Babukusu and other African communities (Nabisiolo, O,I, 2014). A good example is the 1904 and the 1911 Maasai agreements which made the Maasai to migrate from areas around Nairobi to Laikipia and Ngong hills. Coincidentally, the kolongolo age-set of 2000 to 2010 was characterized by the disputed December 2007 presidential election which resulted to internally displaced people in Kenya.

\section{CONCLUSION}

From the foregoing discussion, age-set system among the Babukusu is historical depicting significant historical events and individuals who perpetuated such occurrences. It constitute eight age-sets and there is still more debates regarding the origin and the spread of these age-set nomenclature. However, the rituals associated with this circumcision concept are still in place although the essence of Western influence and Christianity is threatening the erosion of this culture.

\section{REFERENCES}

1. Beruldsen, G. (2003), Australian Bird; Their Nests and Eggs, Queensland; Kenmore.

2. Cognole, C. I. M. C. (1933), The Agikuyu, Their Customs, Traditions and Folklore, Nyeri: Mission Printing School.

3. Dutto, A. C. (1975), Nyeri Townsmen Kenya, Nairobi; EALB.

4. Kakai, W. P. (1992), Social Concept in the Initiation Rituals of the Abatachoni, a Historical Study, M.A Thesis, Nairobi; Kenyatta University Press.

5. KNA, DC/EN/3/2/4: 1929-1935

6. Lihraw, D. O. (2010), The Pre-Independent Kenya, THE TACHON PEOPLES, History, Culture and Economy, Nairobi; PERC-PACE International.

7. Lo Liyong, T, L, (1972), (Eds), Popular Cultures of East Africa, Nairobi; Longman Kenya ltd.

8. Makila, F. E. (1967), An Outline History of the Babukusu from the Roots, Nairobi; E.A.B.L.(1978), An Outline History of the Babukusu of Western in Kenya, Nairobi; K.L.B.(1982), The Significance of Chetambe Fort in Bukusu, Department of Culture official Monograph.

9. Muraya, M. W. (2009), Colonial Transformation of Female Circumcision and its Impact on Women's Roleand Gender Relations Among the Gikuyu of Kiambu From 1895 to 1963, Nairobi; KenyattaUniversity, M.A Thesis.

10. Muraya, M. W. (2009), Colonial Transformation of Female Circumcision and its Impact on Women's Roleand Gender Relations Among the Gikuyu of Kiambu From 1895 to 1963, Nairobi; KenyattaUniversity, M.A Thesis.

11. Mwanzi, A, H. (1977), A History of the Kipsigis, Nairobi, $K L B$.

12. Ochieng', R. (eds), (2002), Historical Studies and Social Change in Western Kenya, Nairobi: East AfricaEducational Publisher.

13. Silverman, E. K. (2004), Anthropology and Circumcision, in a journal of Annual Review ofAnthropology Vol. 33 p 419-45.

14. Wagner, G. (1949), The Bantu of North Kavirondo, vol 1, New York: Oxford University Press. 
15. Wafula, P. W. (2000), Politics and Nationalism in Colonial Kenya: The Case of the Babukusu of Bungoma District, C. 1894-1963, M.A Thesis, Nairobi; Kenyatta University.

16. Wandiba, S. (1983), Some Aspects of the Pastoral Neolithic in Kenya, Paper No. 148, University of Nairobi.

17. Wanyama, M. and Egesah, O. (2015), Ethnography and Ethno-music of Babukusu Traditional MaleCircumcision; Messaging, Symbolism and Rationale, Moi University

18. Wanyama, E. K. (2017), Continuity and change in polygyny in Sirisia Constituency of Bungoma County,Kenya c. 1895-2010. M.A Thesis, Nairobi; Kenyatta University.
19. Wasike, C. (2013), Textualizing Masculinity: Discourses of Power and Gender Relations in Manguliechi's Bukusu After burial Oratory Performance (khuswala kumuse), Unpublished Thesis, Johannesburg, University of Witwatersrand.

20. Were, G. S. (1967a), Western Kenya Historical Texts: Abaluhya, Teso and Elgon Kalenjin, Nairobi; EALB(1967), A History of the Abaluhya of Western Kenya, Nairobi; E.A.L.B.

\section{ORAL EVIDENCE}

\begin{tabular}{|l|c|c|c|c|l|}
\hline Name & Age(Years) & $\begin{array}{c}\text { Interview } \\
\text { Date }\end{array}$ & Village & $\begin{array}{c}\text { Sub- } \\
\text { Location }\end{array}$ & Profession \\
\hline Gabriel Naulikha & 93 & $9-8-2014$ & Matoma & Kamusinde & Retired Teacher \\
\hline Gabriel Murutu & 64 & $13-12-2914$ & Buko & Sikhendu & Retired Teacher \\
\hline Henry Mwambu & 61 & $20-9-2014$ & Buko & Sikhendu & Farmer \\
\hline Hosea Wasike & 83 & $29-9-2014$ & Kaptola & Kamusinga & Retired Doctor \\
\hline Jackson Nabiswa & 91 & $16-8-2014$ & Mayuli & Kamusinde & Retired Teacher \\
\hline Joseph Nyongesa & 65 & $18-11-2014$ & Matoma & Kamusinde & Farmer \\
\hline Patrick Nabisiolo & 77 & $16-11-2014$ & Matoma & Kamusinde & Farmer \\
\hline Richard Makhanu & 55 & $12-11-2015$ & Kahawa & Kahawa & Lecturer \\
\hline
\end{tabular}

